\title{
ASSOCIATION BETWEEN MATERNAL-FETAL GENETIC HISTOCOMPATIBILITY AND MATERNAL UNDERNUTRITION IN MICE: INFLUENCE ON INTRAUTERINE GROWTH
}

Celso M. Rebello and José Lauro A. Ramos

Rebello CM, Ramos JLA. Association between maternal-fetal genetic histocompatibility and maternal undernutrition in mice: influence on intrauterine growth. Clinics. 2006;61(2):127-32.

OBJECTIVE: The purpose of this study was to evaluate the effects of maternal-fetal genetic histocompatibility and the association of that condition with maternal undernutrition regarding fetal growth and litter size.

STUDY DESIGN: Fetuses that were either syngeneic or allogeneic with the mothers were bred, using mice of well-defined syngeneic strains (A/J and Balb/c). Pregnant mice were fed using either unrestricted normal diet with $22 \%$ protein, consumed ad libitum, or a diet containing $14 \%$ protein, with intake restricted to $70 \%$ of that consumed by the unrestricted group. At the end of gestation, the number of fetoplacental units and fetal losses, the fetal and placental weight, and the weights of fetal brain and liver were recorded.

RESULTS: Fetuses from undernourished mothers showed a reduction in body, placental, and brain weight $(P<0.01)$; the association of undernourishment with maternal-fetal genetic compatibility resulted in a greater impairment of fetal growth $(P<0.01)$. A reduction in the number of viable fetuses per female in the dietary-restricted groups was observed. $(P<0.01)$. Although the concurrence of maternal-fetal genetic compatibility resulted in a trend towards a greater reduction in the number of viable fetuses as well as in a higher rate of fetal loss, these differences did not reach statistical significance.

CONCLUSIONS: In mice, the occurrence of maternal-fetal genetic histocompatibility alone did not change fetal growth; maternal undernutrition during pregnancy resulted in growth stunting of progenies with reduction of litter size; and the association of these 2 factors produced greater reduction of fetal weight.

KEYWORDS: Fetal development. Fetal growth retardation. Histocompatibility. Nutrition disorders. Pregnancy.

\section{INTRODUCTION}

Intrauterine growth retardation (IUGR) has been subject of research during the last decades by many investigators. In late 1920s, Capper had already suggested the distinction between the true preterm infant and the term newborn with low birth weight.

The effects of IUGR, defined as a reduction in an expected growth pattern, ${ }^{2}$ have been well studied in clinical

Department of Pediatrics, São Paulo University Medical School - São Paulo/ SP, Brazil.

Email: celso.rebello@uol.com.br

Received for publication on December 07, 2005.

Accepted for publication on January 31, 2006. and experimental research. Using the rat model with in utero dietary restriction, smaller litters and a reduction in birth weight resulted; body weight remained below the control group for 8 months after birth. ${ }^{3}$ In separate studies, Winick and Zamenhof showed a reduction in cell number in many organs, including the brain and placenta, among fetuses of mothers submitted to protein restriction during the gestation period. ${ }^{4,5}$ In guinea pigs and rats, an association has been shown between caloric-proteic restriction and reduced body and brain weight at birth, reduced proteic, lipidic, and cellular brain content, and reduced protein, DNA and RNA in several organs. ${ }^{6,7}$

Many clinical situations can affect fetal growth, falling into the useful categories of maternal (genetic factors, 
nutritional status, chronic diseases resulting in uterine ischemia or hypoxia), placental (chorioangioma, villitis, ischemic villous necrosis), and fetal (chromosome disorders, congenital infections) determinants of IUGR. These situations can explain most of the occurrences of birth weight variability, but approximately $25 \%$ of contributing factors remain unknown. ${ }^{8}$

One theory that explains some of the IUGR of unknown origin is the maternal-fetal genetic compatibility hypothesis proposed by Beer et al, ${ }^{9,10}$ based in his experiments with rats, mice, and hamsters. They postulated that antigenic similarity could result in diminished placental trophoblastic invasion of the decidua, impairing fetal growth. It is now accepted that this reduced fetal growth is due to poor development of the maternal blood supply to the fetoplacental unit because of defective interaction between embryonic trophoblast cells and cells of uterine mucosa. ${ }^{11}$ The same authors suggested that this could also be a cause of habitual abortion in humans. ${ }^{12}$ This theory was also suggested by Hoff and Bixler, ${ }^{13}$ who studied the maternal-fetal $\mathrm{ABO} / \mathrm{Rh}$ antigenic relationship in humans.

Despite these initial studies, the effects of maternal-fetal genetic compatibility on intrauterine growth are not completely understood, and there are no studies evaluating the effects of the association between this clinical situation and other determinants of IUGR, such as maternal undernutrition during gestation. We hypothesized that the combination of maternal-fetal genetic compatibility and maternal undernutrition during gestation would result in a higher impairment of fetal growth and litter size.

\section{METHODS}

Study groups. Using mice of well-defined syngeneic strains (A/J and Balb/c), fetuses that were syngeneic and allogeneic with respect to their respective mothers were bred. Syngeneic and allogeneic animals were provided by the Immunology Research Laboratory - Department of Immunology - Institute of Biomedical Science- University of São Paulo.

A total of 10 females were studied in the allogeneic group with normal nutrition, 11 in the syngeneic group with normal nutrition, 11 in the allogeneic group with maternal undernutrition, and 10 in the syngeneic group with maternal undernutrition. Pregnancy was assumed to have begun after mating confirmation by the finding of a vaginal plug.

The first group of pregnant females, syngeneic with their fetuses were accommodated in individual cages and fed ad libitum, using a standard mouse diet with additives for isogenic mice strains and containing $22 \%$ protein in the composition (Table 1) Body weights and diet consumption
Table 1 - Energy and nutrient content of the diets from both groups

\begin{tabular}{lcc}
\hline & Standard mice diet & $\begin{array}{c}\text { Special diet } \\
\text { with 14\% protein * }\end{array}$ \\
\hline Energy (kcal/kg) & 3300 & 2980 \\
Raw protein (\%) & 22 & 14 \\
Raw fat (\%) & 5 & 5 \\
Raw fiber (\%) & 3 & 3 \\
Calcium (\%) & 0.8 & 0.8 \\
Phosphorus (\%) & 0.7 & 0.7 \\
Sodium (\%) & 0.2 & 0.2 \\
Potassium (\%) & 0.7 & 0.7 \\
Magnesium (\%) & 0.2 & 0.2 \\
Iron (ppm) & 200 & 200 \\
Manganese (ppm) & 50 & 50 \\
Zinc (ppm) & 50 & 50 \\
Copper (ppm) & 15 & 15 \\
\hline
\end{tabular}

* Animals receiving special diet with $14 \%$ protein had a consumption restriction limited to $70 \%$ of the mean intake observed among the animals of the unrestricted group

were recorded daily. A second group, of pregnant females allogeneic with their fetuses received the same treatment. Groups 3 and 4 of pregnant females, respectively syngenic and allogenic with their fetuses, were fed using a special diet containing $14 \%$ protein and the same amount of fat and carbohydrates per gram, with a consumption restriction to $70 \%$ of the mean intake observed among the animals of a pilot unrestricted group.

Diets from both groups were prepared by the Experimental Laboratory of the Department of Pediatrics,Botucatu Medical School (State University of São Paulo UNESP).

Delivery and fetal manipulation. Following the recording of body weight, pregnant mice were euthanized with ether on day 19 of gestation. After incision of the abdomen and uterus, each fetoplacental unit was removed, and their number was recorded. The uterus was removed from abdomen, opened under 20x magnification, and the fetal losses were identified and recorded. The membranes were removed from each fetoplacental unit, the umbilical cord was sectioned next to the abdomen, and each fetus and placenta was well dried; this was followed by the recording of the fetal and placental weights. Each fetus was dissected under a 20x magnification, with removal and weighing of the brain and liver.

Data analysis. Comparisons between groups was using ANOVA one way, with Student-Newman-Keuls as the post hoc test. Proportions were compared using the $z$ test with Yates correction. Significance was set at 0.05 .

\section{RESULTS}

The maternal weight gain during gestation, the mater- 
nal weight gain normalized by the total number of fetuses (viable fetuses + fetal losses), the mean daily diet consumption, as well as the data regarding the number of fetuses and fetal losses are shown in the Table 2. Although females that were allowed normal nutrition had better weight gain than those submitted to diet restriction $(P<0.01)$, the weight gain normalized by the number of viable fetus showed differences only between both syngeneic groups against the corresponding allogeneic groups $(P<0.01)$.

$A$ reduction in the number of viable fetuses per female among both groups submitted to diet restriction during gestation compared to the groups with normal nutrition was observed. $(P<0.01)$. Although the occurrence of maternal-fetal genetic compatibility resulted in a trend towards a reduction in the number of viable fetuses among females with normal or restricted diet, this difference did not reach statistical significance. Similarly, there was a trend towards an increase in the rate of the fetal loss and relative fetal loss (fetal loss/total number of fetus x 100) among the animals submitted to diet restriction during gestation, again without reaching statistical significance.

Animals submitted to caloric-proteic restriction during gestation showed a reduction in body weight at birth, and the combination of this dietary restriction with maternalfetal genetic compatibility resulted in a greater impairment of fetal growth $(P<0.01)$ (Figure 1$)$. The placental and brain weights also were reduced among animals of both groups submitted to maternal undernutrition, although there was no influence of maternal-fetal genetic compatibility (Figures 2 and 3). There was no difference among the study groups regarding liver weight (Figure 4).

Table 2 - Description of animal numbers, maternal weight gain, diet consumption, number of viable fetuses per female, and total and relative fetal loss for each study group ( mean $\pm \mathrm{SD})$

\begin{tabular}{|c|c|c|c|c|}
\hline & \multicolumn{2}{|c|}{ Normal nutrition } & \multicolumn{2}{|c|}{ Maternal undernutrition } \\
\hline & Syngeneic & Allogeneic & Syngeneic & Allogeneic \\
\hline Females (n) & 11 & 10 & 10 & 11 \\
\hline Maternal weight gain (g) & $13.2 \pm 4.5 \dagger$ & $10.8 \pm 3.1 \dagger$ & $6.0 \pm 2.0$ & $5.9 \pm 1.9$ \\
\hline Maternal weight gain/viable fetus (g) & $3.0 \pm 0.7 *$ & $2.0 \pm 0.5$ & $2.9 \pm 1.3 *$ & $1.8 \pm 0.2$ \\
\hline Diet consumption (g/day) & $5.2 \pm 1.2 \dagger$ & $4.4 \pm 1.0^{\dagger}$ & $3.4 \pm 0.1$ & $3.2 \pm 0.4$ \\
\hline Viable fetuses per female (n) & $4.6 \pm 2.4 \dagger$ & $5.6 \pm 1.8 \dagger$ & $2.5 \pm 1.4$ & $3.5 \pm 1.6$ \\
\hline Fetal loss (n) & $1.4 \pm 1.2$ & $1.6 \pm 1.6$ & $2.1 \pm 1.5$ & $2.4 \pm 1.4$ \\
\hline Relative fetal loss (\%) & $24.4 \pm 14.2$ & $21.6 \pm 18.8$ & $40.8 \pm 27.1$ & $40.0 \pm 21.4$ \\
\hline Total of fetuses $/$ female & $5.5 \pm 2.4$ & $7.3 \pm 2.4$ & $4.6 \pm 2.2$ & $5.9 \pm 1.2$ \\
\hline
\end{tabular}

$f$ Viable fetuses + fetal losses. $\dagger P<0.01$ vs maternal undernutrition. $* P<0.01$ vs allogeneic

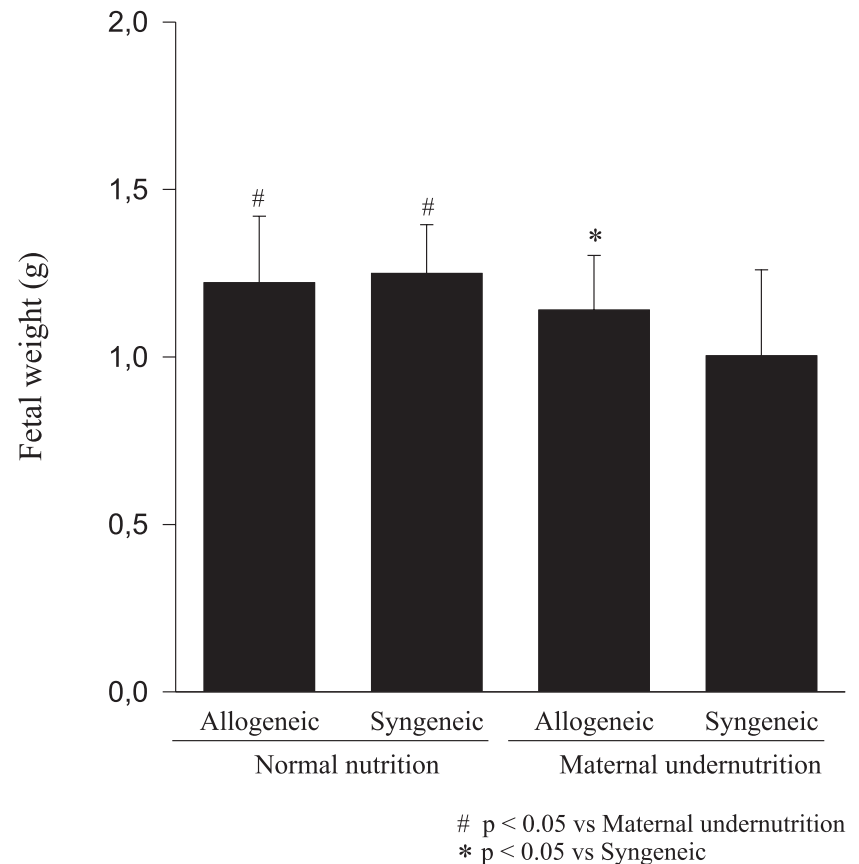

Figure 1 - Effect of type of maternal diet and maternal-fetal genetic compatibility on fetal weight (mean $\pm \mathrm{SD}$ )

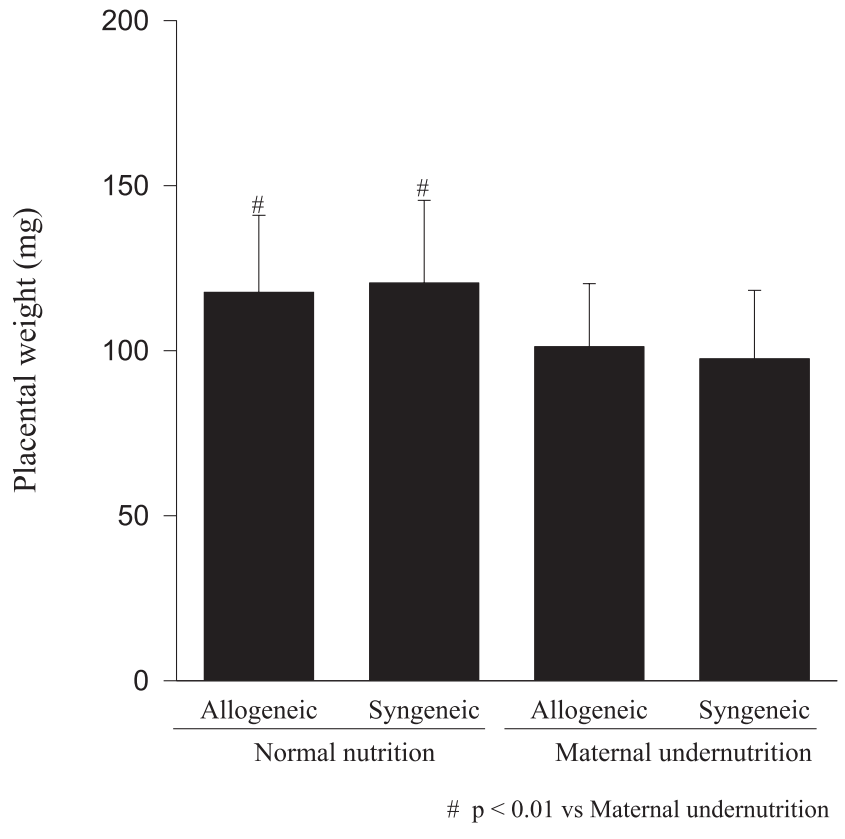

Figure 2 - Effect of type of maternal diet and maternal-fetal genetic compatibility on placental weight (mean $\pm \mathrm{SD}$ ). 


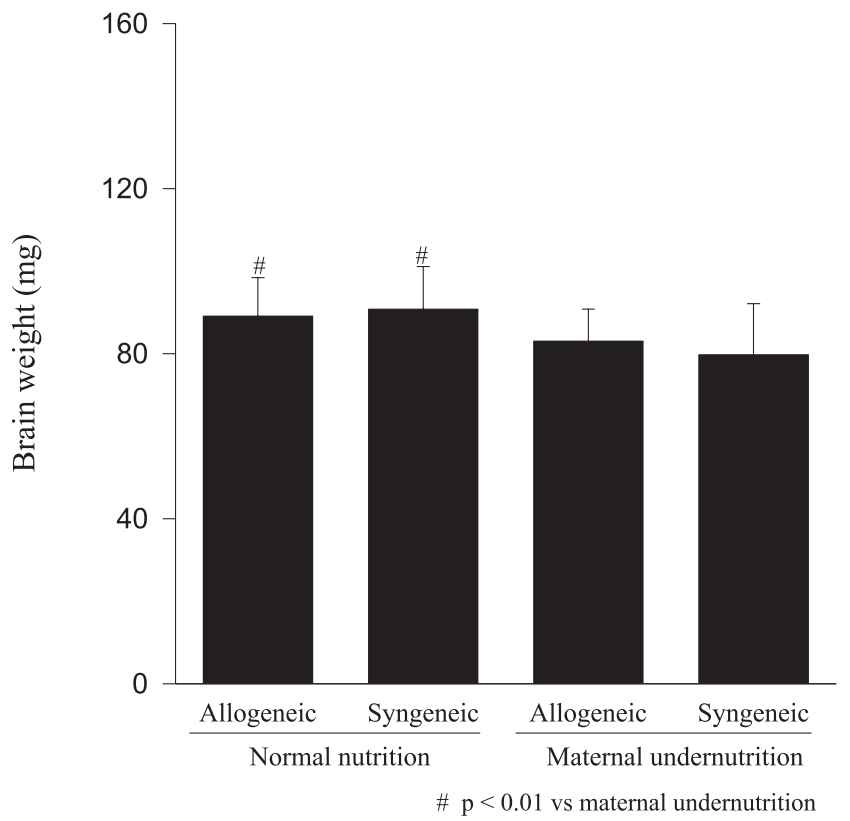

Figure 3 - Effect of type of maternal diet and maternal-fetal genetic compatibility on fetal brain weight (mean $\pm \mathrm{SD}$ ).

\section{DISCUSSION}

The choice of the mouse as the experimental model was based on experiments reported in the literature on IUGR with this animal model ${ }^{14,15}$ combined with the possibility of studying distinct genetic strains. We used a higher caloric restriction than was used in the study of Chow and Lee, ${ }^{3}$ in which the nutritional intake in rats during the entire gestational period was limited to $75 \%$ of that observed among the animals of the control group. The $14 \%$ protein restriction was based in the study of Zeman and Stanbrough, ${ }^{7}$ which demonstrated lower protein content in liver and other organs, as well as a reduction in fetal cellular content beginning at day 4 of gestation among rats submitted to a $6 \%$ protein restriction compared to controls fed with diet containing $30 \%$ proteins. The protein content of the diet was also influenced by the results of a pilot study, in which we observed total fetal loss using a diet with a total of $5 \%$ protein, and the same consumption restriction of $70 \%$ of the mean intake observed among the animals of the unrestricted group, obtaining a fetal mortality of approximately $100 \%$ (data not shown). This protein restriction was also based in the findings of Stewart and Sheppard, ${ }^{16}$ who obtained a reduction in the litter size in rats submitted to caloric-proteic restriction during gestation. The time of pregnancy termination (19 days of gestation) was chosen in order to be as close as possible to the end of gestation, allowing the maximum possible differences regarding the fetal and organ weights among the study groups.

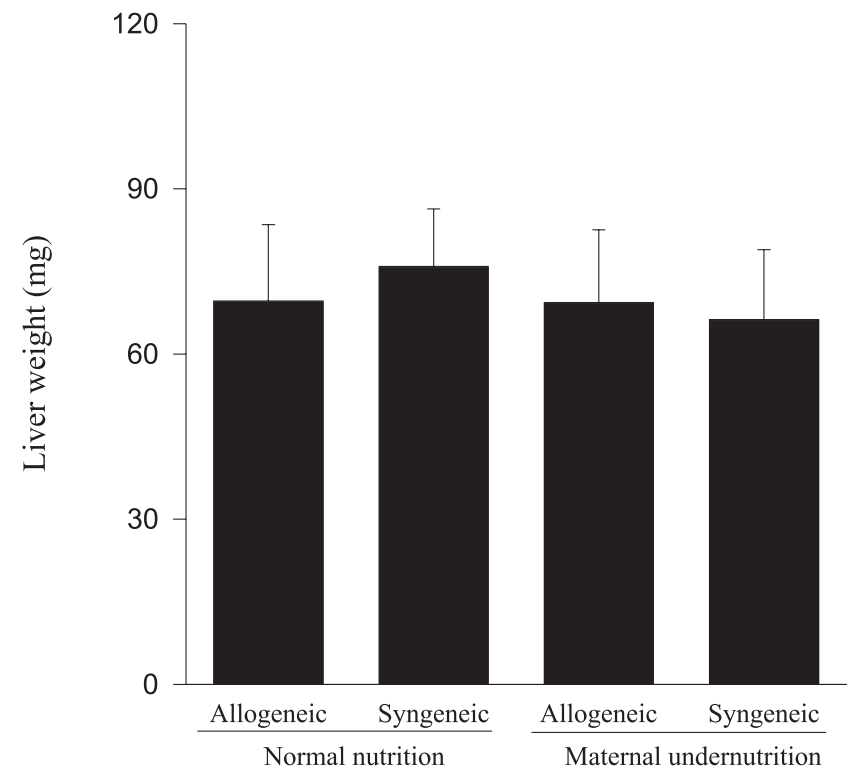

Figure 4 - Effect of type of maternal diet and maternal-fetal genetic compatibility on fetal liver weight (mean \pm SD).

Our data confirms that the model of maternal undernutrition used in this study successfully resulted in an in utero deprivation. In fact, the findings of a reduction in fetal, brain, and placental weights related to the maternal undernutrition observed among fetuses of allogeneic and syngeneic pregnancies were expected, and they are in accordance to the data reported in the literature, in which a reduction in fetal, placental, brain, liver, lung and kidney weight, as well as a reduction in DNA content, following maternal protein restriction during gestation was demonstrated. ${ }^{17}$

We investigated the influence of maternal-fetal genetic compatibility on fetal development, and we unexpectedly found little influence of this situation on intrauterine growth. The analysis of the influence of the immunogenetic disparity between the conceptus and its mother on placental and fetal weight produced different results from those found by Beer et al, ${ }^{10}$ who found that interstrain matings resulting in genetic differences between mother and their conceptuses resulted in heavier placentas and fetuses, and they postulated that maternal reactivity against fetal alloantigens could be an important determinant of deciduation and, therefore, fetoplacental weight. Additional evidence that maternal-fetal histoincompatibility would be favorable to the fetuses was provided by Michie and Anderson, ${ }^{18}$ who reported better survival among heterozygotes after 72 generations of brother $\mathrm{x}$ sister matings of Wistar rats. Those findings could be related to a better expression of cell adhesion molecules of the extravillous trophoblast in the case of syngeneic mothers 
and fetuses, which could interfere with fetal growth. ${ }^{19}$ Further support to this theory was given through the finding in humans of slowed fetal growth associated with lack of maternal immune exposure to fetal HLA antigens. ${ }^{20}$ Our data suggests that the immunogenetic similarity between mother and fetus does not induce significant IUGR, although this condition can enhance the effect of other determinants of IUGR. Similar results were found by Verp et $\mathrm{al},{ }^{21}$ who studied the effect of HLA-DQA1 compatible pregnancies on fetal growth. These authors concluded that HLA compatibility per se is not associated with inhibition of fetal growth, although HLA compatibility could have an effect in women with history of spontaneous abortion.

We also evaluated the influence of the immunogenetic status between mother and fetus and maternal undernutrition with regard to the number of viable conceptuses and fetal loss. Our data on the effects of maternal undernutrition on litter size are in accordance with the results of Chow and Lee, ${ }^{3}$ who reported a reduction in the number of newborns from rats submitted to dietary restriction during gestation. It is interesting to observe that the maternal weight gain during gestation normalized by the fetal number was similar when we compared the 2 groups with normal nutrition to the 2 undernourished groups, showing that the undernourished mothers did not sacrifice their own tissue to favor the fetuses.

When the influence of immunogenetic similarity between mother and fetus on litter size was tested, we found a trend towards the reduction in the number of viable fetuses and an increase in the number of fetal losses, but nei- ther of these reached statistical significance. In contrast to the observations regarding fetal growth, we did not find an additive effect between the immunogenetic status between mother and fetus and maternal undernutrition on litter size. Here again, our results are not in accordance with the findings of Beer et al, ${ }^{10}$ who found that genetic disparity between mother and fetus significantly increased litter size in hamsters, particularly with the pre-sensitization of the females to paternal tissue antigens.

Our results contribute to a better understanding of changes in fetal growth related to the immunogenetic status between mother and fetus; however, it is also clear that the determinants of fetal growth under various immunogenetic conditions are still incompletely understood. Perhaps research focusing on the mechanisms by which maternalfetal genetic compatibility is involved in the control of the interaction between the invading trophoblast and the uterine decidua, particularly regarding how the vascular invasion by trophoblast is modulated, will better explain the influence of immunogenetic status between mother and fetus on fetal development.

\section{ACKNOWLEDGMENTS}

The authors thanks Cleide P. Trindade M.D. Ph D., Professor of Pediatrics, Botucatu Medical School (UNESP), for providing the diet, and Magda M. S. Carneiro Sampaio M.D. Ph D., Department of Immunology - Institute of Biomedical Science - University of São Paulo, for providing the laboratory structure and the animals for this study.

\section{RESUMO}

Rebello CM, Ramos JLA. Associação entre histocompatibilidade genética materno-fetal e desnutrição materna em camundongos: influência no crescimento fetal. Clinics. 2006;61(2):127-32.

OBJETIVO: Avaliar os efeitos da histocompatibilidade genética materno-fetal e sua associação com a desnutrição materna em relação ao crescimento fetal e número de fetos. MÉTODOS: Fetos singênicos ou alogênicos em relação às respectivas mães foram obtidos através de cruzamentos de camundongos com linhagens genéticas bem definidas (A/J e Balb/c). As fêmeas grávidas foram alimentadas $a d$ libitum com dieta normal contendo $22 \%$ de proteínas ou dieta com restrição, contendo $14 \%$ de proteína e aporte máximo de $70 \%$ do total consumido pelo grupo em dieta livre. No final da gestação, o número de unidades feto- placentárias e de perdas fetais, o peso da placenta e do feto, assim como o peso do cérebro e do fígado foram anotados. RESULTADOS: Os fetos das mães submetidas à desnutrição mostraram redução no peso corpóreo, placentário e cerebral $(\mathrm{p}<0.01)$, sendo que a associação entre a compatibilidade genética materno-fetal resultou em maior restrição ao crescimento fetal $(\mathrm{p}<0.01)$. Foi observada uma redução no número de fetos viáveis por fêmea entre os animais do grupo de restrição nutricional $(\mathrm{p}<0.01)$. Embora a ocorrência de compatibilidade genética materno-fetal tenha resultado na redução do número de fetos viáveis e numa tendência ao aumento de perdas fetais, esta diferença não foi significante.

CONCLUSÕES: Em camundongos, a ocorrência de histocompatibilidade genética materno-fetal não modificou o crescimento fetal; a desnutrição materna durante a 
gestação resultou em retardo de crescimento fetal com menor tamanho da ninhada, e a associação dos dois fatores aumentou a redução do peso fetal.
UNITERMOS: Crescimento fetal. Retardo de crescimento intra-uterino. Histocompatibilidade. Distúrbios nutricionais. Gestação.

\section{REFERENCES}

1. Capper A. Fate and development of the immature and of the premature child. Clinical study. Am J Dis Child. 1928;35:262-5.

2. Sanderson DA, Wilcox MA, Johnson IR. The individualised birthweight ratio: a new method of identifying intrauterine growth retardation. Br J Obstet Gynaecol. 1994;101:310-4.

3. Chow BF, Lee CJ. Effect of dietary restriction of pregnant rats on body weight gain of the offspring. J Nutrition. 1964;82:10-8.

4. Winick M, Rosso P. The effect of severe early malnutrition on cellular growth of human brain. Ped Res. 1969;3:181-4.

5. Zamenhof S, van Marthens E, Grauel L. DNA (cell number) and protein in neonatal brain: alteration by maternal dietary protein restriction. Science. 1968;160:322-3.

6. Chase HP, Dabiere CS, Welch NN, O'Brien D. Intra-uterine undernutrition and brain development. Pediatrics. 1971;47:491-500.

7. Zeman FJ, Stanbrough EC. Effect of maternal protein deficiency on cellular development in the fetal rat. J Nutrition. 1969;99:274-82.

8. Kliegman RM: Intrauterine growth retardation. In: Fanaroff AA, Martin RJ, editors, Neonatal-perinatal medicine: diseases of the fetus and newborn infant, Vol II. St. Louis: Mosby; 1997.

9. Beer AE, Billinghan RE, Scott JR: Immunogenetic aspects of implantation, placentation and feto-placental growth rates. Biol Reproduction. 1975;12:176-89.

10. Beer AE, Scott JR, Billinghan RE. Histoincompatibility and maternal immunological status as determinants of fetoplacental weight and litter size in rodents. J Exp Med. 1975;142:180-96.

11. King A, Loke YW. Unexplained fetal growth retardation: what is the cause? Arch Dis Child Fetal Neonatal Ed. 1994;70:F225-7.
12. Beer AE, Quebbeman J, Ayers JWT, Haines RF. Major histocompatibility complex antigens, maternal and paternal immune responses, and chronic habitual abortions in humans. Am J Obstet Gynecol. 1981;141:987-99.

13. Hoff C, Bixler C. Maternal-fetal ABO/Rh antigenic relationships and human fetal development. Am J Obstet Gynecol. 1986;154:126-9.

14. Li D, Pickell L, Liu Y, Wu Q, Cohn JS, R Rozen. Maternal methylenetetrahydrofolate reductase deficiency and low dietary folate lead to adverse reproductive outcomes and congenital heart defects in mice. Am J Clin Nutr. 2005;82:188-95.

15. Kirkwood TB, Shanley DP. Food restriction, evolution and ageing. Mech Ageing Dev. 2005;126:1011-6.

16. Stewart RJ, Sheppard HG. Protein-caloric deficiency in rats. Growth and reproduction. Br J Nutr. 1971;25:175-80.

17. Brasel JN, Winick M. Maternal nutrition and prenatal growth Experimental studies of effects of maternal undernutrition on fetal and placental growth. Arch Dis Child. 1972;47:479-85.

18. Michie D, Anderson NF. A strong selective effect association with a histocompatibility gene in the rat. Ann N Y Acad Sci. 1966;129:88-94.

19. Zygmunt M, Boving B, Wienhard J, Munstedt K, Braems G, Bohle RM, et al. Expression of cell adhesion molecules in the extravillous trophoblast is altered in IUGR. Am J Reprod Immunol. 1997;38:295301 .

20. Hoff C, Peevy KJ, Spinnato JA, Giattina K, Peterson RD. Association between maternal-fetal HLA-DR relationships and fetal growth. Am J Reprod Immunol. 1993;30:246-53

21. Verp MS, Sibul M, Billstrand C, Bellen G, Hsu M, Ober C. Maternalfetal histocompatibility in intrauterine growth retarded and normal weight babies. Am J Reprod Immunol. 1993;29:195-8. 